\title{
Ergenlerin Mükemmeliyetçi Öz Sunum Düzeyleri İle Sosyal Görünüş Kaygıları ve Benlik Saygıları Arasındaki İlişki ${ }^{1}$
}

DOI: $10.26466 /$ opus.924759

$*$

\author{
Ahmet Koçyiğit* - Ali Fuat Yalçın ${ }^{* *}$ \\ * Yl. Öğrencisi, Necmettin Erbakan Üniversitesi, Konya/Türkiye \\ E-Posta: ahmet.kocyigit27@gmail.com \\ ORCID: $\quad \underline{0000-0003-4190-3858}$ \\ ** Dr. Öğr. Üyesi, Necmettin Erbakan Üniversitesi, Konya/Türkiye \\ E-Posta: $\underline{\text { dr alifuatyalcin@yahoo.com }}$ \\ ORCID: $\underline{0000-0001-6088-3720}$
}

Öz

Bu araştırmada, ergenlerin mükemmeliyetçi öz sunum düzeyleri ile sosyal görünüş kaygıları ve benlik saygıları arasındaki ilişki incelenmiştir. Araştırmada ayrıca mükemmeliyetçi öz sunumun cinsiyet ve okul türü (özel/devlet) değişkenlerine göre farklılaşıp farklılaşmadığını ortaya koymak amaçlanmıştır. Araştırmanın çalışma grubunu 2020-2021 yılında Konya ili merkez ilçelerinde bulunan liselerde eğitim gören 527 lise öğrencisi oluşturmaktadır. Araştırmada "Çocuk ve Ergenlerde Mükemmeliyetçi Öz Sunum Ölçeği", "Sosyal Görünüş Kaygısı Ölçeği", "Rosenberg Benlik Saygısı Ölçeği-Kısa Form" ve "Kişisel Bilgi Formu" kullanılmıştır. Verilerin analizinde değişkenler arasındaki ilişkiyi ortaya koymak amacıyla Pearson Momentler Çarpım Korelasyon Katsayısı, ilgili değiş̧kenler arasındaki yordayıcı ilişkileri belirlemek amacıyla Çoklu Regresyon Analizi ve ilgili değişkenlerin demografik bilgiler açısından incelenmesi için $T$ Testi kullanılmıştır. Araştırmanın sonuçlarına göre mükemmeliyetçi öz sunum ile sosyal görünüş kaygısı arasında pozitif yönde orta düzeyde; mükemmeliyetçi öz sunum ve benlik saygısı arasında ise negatif yönde orta düzeyde anlamlı ilişki tespit edilmiştir. Sosyal görünüş kaygısı ve benlik saygısının mükemmeliyetçi öz sunumu yordadı̆̆ görülmüştür. Mükemmeliyetçi öz sunumun hatanın gizlenmesi alt boyutunun devlet okulunda okuyan ergen öğrencilerde, özel okulda okuyanlara göre anlaml şekilde farklılaştığı ama diğer alt boyutların okul türüne göre farklılaşmadığı sonucu ortaya çıkmıştır. Mükemmeliyetçi öz sunumun ü̧̈ alt boyutunun da cinsiyete göre farklılaşmadığı görülmüştür.

Anahtar Kelimeler: Mükemmeliyetçi öz sunum, sosyal görünüş kaygısı, benlik saygısı, ergen.

\footnotetext{
1 Ahmet KOÇYiĞiT tarafından, Dr. Öğr. Üyesi Ali Fuat YALÇIN danışmanlığında, Necmettin Erbakan Üniversitesi, Eğitim Bilimleri Enstitüsünde 2021 yılında yapılan yüksek lisans tezinden yararlanılarak oluşturulmuştur.
} 
ISSN:2528-9527

E-ISSN: 2528-9535

YIl Year: 11

Cilt Volume: 18

Sayı Issue: Eğitim Bilimleri Özel Sayısı

Eylül September 2021

Uluslararası Toplum Araştırmaları Dergisi

International Journal of Society Researches

Makalenin Geliş Tarihi Received Date: 21/04/2021

Makalenin Kabul Tarihi Accepted Date: 26/06/2021

\title{
The Relationship Between Adolescents Perfectionistic Self-Presentation Levels and Social Appearance Anxiety and Self-Esteem
}

$*$

\begin{abstract}
In this study, the relationship between the perfectionistic self-presentation levels of adolescents and their social appearance anxiety and self-esteem was examined. The study also aimed to reveal whether the perfectionistic self-presentation differs according to gender and type of school (private / state) variables. The study group of the research consists of 527 high school students studying in high schools located in the central districts of Konya at 2020-2021. "Perfectionistic Self-Presentation Scale in Children and Adolescents", "Social Appearance Anxiety Scale", "Rosenberg Self-Esteem ScaleShort Form" and "Personal Information Form" were used in the study. In the analysis of the data, the Pearson Moments Multiplication Correlation Coefficient was used to reveal the relationship between the variables, the Multiple Regression Analysis to determine the predictive relationships between the relevant variables, and the $T$ Test to examine the relevant variables in terms of demographic information. According to the results of the study, there is a positive medium level between perfectionistic self-presentation and social appearance anxiety; A moderately significant negative correlation was found between perfectionistic self-presentation and self-esteem. It was seen that social appearance anxiety and self-esteem predicted perfectionistic self-presentation. The conclusion that the sub-dimension of hiding error of perfectionistic self-presentation differs significantly among adolescent students studying at public school compared to those studying at private school, but the other subdimensions do not differ according to school type. It was observed that the three sub-dimensions of perfectionist self-presentation did not differ by gender.
\end{abstract}

Key Words: Perfectionistic self presentation, social appearance anxiety, self esteem, adolescent. 


\section{Giriş}

Mükemmeliyetçi öz-sunum, Hewitt ve Flett (1993) tarafından, kendini başkalarına mükemmel olarak gösterme ve kusurluluk görünüşünden kaçınma davranışlarıyla kendini gösteren bir teorik bir yapı olarak tanımlanmıştır. Hewitt ve diğerleri (2003), yetişkinlerdeki mükemmeliyetçi öz- sunum boyutlarını ölçmek için geliştirdikleri Mükemmeliyetçi Öz-Sunum Ölçeği'nde, mükemmeliyetçi öz-sunumun; mükemmeliyetçi öz yükseltme, hatanın gizlenmesi ve hatanın söylenmemesi adlı üç alt boyuttan oluştuğunu belirlemişlerdir. Mükemmeliyetçi öz-yükseltme, bir kişinin, kendisini başkalarına mükemmelmiş gibi tanıtma ihtiyacını anlatan bir öz-sunum tarzının karşılığıdır. Mükemmeliyetçi öz- yükseltme ile kişi, başka insanların saygısını ve onayını kazanabilmek için onları etkilemeye çalışır. Bu, kusursuz bir görüntüyü iletişim ortamına getirmeyi ve diğer insanların gözünde iyi bir noktaya gelmeyi temel alan bir çabadır.

Hatanın gizlenmesi, mükemmel olmayan davranışların apaçık görülmesine dair yaşanan kaygıyı yansıtan ögelerden oluşur. Kusurlu görünmenin ve mükemmel olmayan davranışların engellenmesini, ortaya çıabilecek hataların diğer insanlardan gizlenmesini ve bunun için gösterilen tüm çabaları içerir. Hatanın söylenmemesi, hatanın ya da kusurun açıklanmasından ya da kabul edilmesinden kaçınma ihtiyacını yansıtır. Hataların ve kusurların itiraf edilmesinden kaçınmakla birlikte ortaya çıkan hata ve kusurların kabul edilmemesi durumu vardır. Temelinde reddedilme korkusu yatan bu davranışta bireyler, hatalarının açıkça ortada bulunmasının bir ret doğuracağını düşündügünden kusurlarının açılanmasından kaçınırlar. Bu durum yakın ve samimi ilişkiler kurulmasını engeller (Hewitt vd., 2003).

Mükemmeliyetçi öz sunum kavramına bakıldığında, bireyin sosyal ortamda insanlara karşı kendisini mükemmel gösterme çabası göze çarpmaktadır. Kendini olduğundan daha iyi gösterme çabası, hata yapabileceği faaliyetlerden kaçınma ve var olan hatalarını dile getirmeme, inkâr etme gibi davranışlar; bireyin iletişim halinde olduğu bireyler üzerinde iyi bir etki bırakmak istemesiyle ilgilidir. Leary ve Kowalski (1995)'e göre, bireyler başka bir insana kendilerini tanıtmak isterlerken, bazı zamanlarda karşılarındaki kişiler üzerinde istedikleri 
izlenimi ve etkiyi bırakabilmek konusunda kendi özelliklerinden şüpheye düşerler. Böyle bir durum oluştuğunda bireylerin sosyal kayg1 yaşama ihtimalleri ortaya çıkar.

Sosyal anksiyetenin bir türü olan sosyal görünüş kaygısı, kişilerin fiziksel görünüşlerinin başkaları tarafından değerlendirilmesi esnasında hissettikleri gerginlik ve kaygı durumu şeklinde tanımlanmaktadır (Hart vd., 1989). Ancak bu kaygılar bireylerin yalnızca vücutlarının şeklinden dolayı oluşan kaygılar değildir. Daha genel ve bütüncül bir kaygıdır. Yani boylarının uzunluğu, kiloları, yüzlerinin şekli gibi sebeplerle ortaya çıkan kaygıları da içine alır (Hart vd., 2008). Bireyin beden imajı algısı ile, yani vücudunu nasıl algıladığıyla görünüş kaygısı direkt bir ilişki vardır (Cash ve Fleming, 2002).

Beden imajı, kişinin fiziki görünümü ile alakalı duygu, inanç, davranış ile düşüncelerini kapsayan bir kendilik algisı olarak ifade edilmektedir (Cash ve Pruzinsky, 1990). Ergenlik dönemi, beden imajının oluşmasında kritik bir evre olarak bilinmektedir. Ergenlik döneminde yaşanan ani değişiklikler ergen bireyin olumlu beden imaj1 kazanmasında olumsuz etkiler oluşturabilmektedir (Özcan vd., 2013). Ergenlerde sağlıklı bir beden imajının oluşturulamaması sosyal görünüş kaygısına neden olmaktadır. Bireyin dış görünüşü ile alakalı hissettiği kaygı ile birlikte başka insanların onu değerlendirmesi ile ilgili yaşadığı kaygıların tümü sosyal görünüş kaygısı ile ifade edilmektedir. Yani sosyal görünüş kaygısı beden algısının olumsuz olmasına bağlı olarak yaşanan anksiyete olarak tanımlanabilmektedir (Doğan, 2010). Beden imajı kişinin benlik saygısını etkilediği için önemlidir. Benlik saygısının yüksek olması ile olumlu beden imajı ilişkilendirilirken, benlik saygısının düşük olması ise olumsuz beden imajı ile ilişkilendirilir (Jung ve Lee, 2006). Birey beden imajı ve görünüşünün olumsuz algılanması ve olumsuz değerlendirilmesi sonucunda sosyal görünüş kaygısı yaşamaktadır (Karakuş ve Kılıç, 2016).

Kişinin kendisini ne şekilde tanımladığıyla alakalı kapsamlı bir kavram olan benlik kavramından ziyade benlik saygısı, bireyin kendisini onaylaması ve kıymetli olarak görmesiyle alakalı bir kavramdır. Kişinin kendi benliğini beğenmesine ve kıymetli bulmasına dair ortaya çıkan derece, benlik saygisı olarak tanımlanabilir (Adams, 1995). Benlik saygisı yüksek olan bireylerin kendi zihinsel kapasiteleri ile ilgili beklentileri de, 
özgüvenleri de yüksek olur. Bu kişiler istekli sosyal davranışlar gösterirler ve sosyal ilişkilerinde atılgandır. Buna karşılık benlik saygısı düşük olan bireylerin ise özgüveni azalmış durumdadır. Fikirlerinin diğer insanlar tarafından kabul görmeyeceğini düşünerek daha pasif ve çekingen davranırlar (Sarıçam, 2011). Benlik saygısı yüksek olan kişiler daha az hata yaparken, başarıları daha yüksek olmaktadır, bu durumun neticesinde de kendilerini daha kıymetli ve önemli hissetmektedirler (Karadağ vd., 2008). Benlik saygısının yüksek olması, iyimserlikle, kendine güvenle, etkin baş etme mekanizmalarının kullanımıyla, fiziksel ve ruhsal sağlığın yerinde oluşuyla da ilişkilidir. Yüksek benlik saygısına sahip olan bireyler olaylara ve insanlara, başarılı olacakları ve iyi karşılanacakları beklentisi ile yaklaşırlar (Çetinkaya ve Başbakkal, 2005).

Ergenlik dönemi fiziksel olarak hızlı değişim ve gelişimlerin olduğu bir dönemdir. Ayrıca bu dönemde birey kimlik kazanma çabası içindedir. Yaşanan değişimler ve gelişim görevleri de düşünüldüğünde bireyin kendi bedenine dönük olduğu bu dönemde görünüşü ile daha çok ilgilendiği literatürde de görülmektedir. Görünüşünü bu kadar önemseyen ergen, girdiği sosyal ortamlarda dişarıdan nasıl görüldüğüne ve nasıl değerlendirildiğine dair bir kaygı yaşayabilmektedir. Beğenilmek ve kendini beğenmek bu dönemde her zamankinden daha önemlidir. Bireyin kendisi ile ilgili birçok alanda değerlendirme yapması ve kendini beğenip beğenmemesi ise onun benlik saygısını ortaya koyacaktır. Bu yüzden ergenlik, benlik saygısının oluşumu ve gelişimi için de çok önemli bir zaman dilimidir. Tüm bu sürece bakıldığında ve literatür değerlendirildiğinde birçok değişim yaşayan ergenin girdiği sosyal ortamlarda kendisini mükemmel olarak gösterme isteği de davranışı da görülebilmektedir. Bu bağlamda bakıldığında ülkemizde mükemmeliyetçi öz sunum kavramı ile ilgili çalışmaların sınırlı olması ve kavramın sosyal görünüş kaygısı ve benlik saygısı ile birlikte incelenmesinin, ergen bireylerin davranışlarını açıklamada yol gösterici olmasının beklenmesi açısından bu çalışma önem arz etmektedir. Yapılan çalışmanın değişkenlerinin ülkemizde birlikte çalışılmamış olmasının, alana yenilikler getirmesi beklenmektedir. 


\section{Araştırmanın Amacı}

$\mathrm{Bu}$ araştırmanın genel amacı ergenlerin mükemmeliyetçi öz sunum düzeyleri ile sosyal görünüş kaygıları ve benlik saygıları arasındaki ilişkinin incelenmesidir.

\section{Araştırmanın Alt Amaçları}

1. Ergenlerin mükemmeliyetçi öz sunum düzeyleri cinsiyet açısından farklılaşmakta mıdır?

2. Ergenlerin mükemmeliyetçi öz sunum düzeyleri devlet okulunda ya da özel okulda okumalarına göre farklılaşmakta midir?

3. Ergenlerin mükemmeliyetçi öz sunum düzeyleri ile sosyal görünüş kaygıları ve benlik saygıları arasında anlamlı bir ilişki var midır?

4. Ergenlerin sosyal görünüş kaygıları ve benlik saygıları, mükemmeliyetçi öz sunumlarını yordamakta mıdır?

\section{Yöntem}

Bu bölümde araştırmanın modeli, çalışma grubu, veri toplama araçları ve verilerin analizinde kullanılan yöntem ve teknikler ile alakalı bilgi verilmiştir.

\section{Araştırma Modeli}

$\mathrm{Bu}$ araştırma, mevcut durumu sorgulayan betimsel bir araştırmadır ve genel tarama modelinin bir alt türü olan ilişkisel tarama modelindedir. Genel tarama modelleri çok sayıda elemandan oluşan bir evrende, evren hakkında genel bir yargıya varmak amacı ile evrenin tümü ya da ondan alınacak bir grup, örnek ya da örneklem üzerinde yapılan taramalardır. Genel tarama modelleri ile tekil ya da ilişkisel taramalar yapılabilir. İlişkisel tarama modelleri, iki ve daha çok sayıdaki değişken arasında birlikte değişim varlığını veya derecesini belirlemeyi amaçlayan araştırma modelleridir (Karasar, 2016). 


\section{Çalışma Grubu}

Araştırmanın çalışma grubunu 2020-2021 yılında Konya ili merkez ilçelerinde bulunan liselerde eğitim gören öğrencilerin cinsiyet ve devlet okulunda ya da özel okulda okumalarına göre amaçlı örnekleme yöntemi olan maksimum çeşitlilik örnekleme yöntemi ile seçilen 527 lise öğrencisi oluşturmaktadır. Tablo 1'de katılımcıların cinsiyet ve devlet/özel okul türü açısından betimsel istatistikleri verilmiştir.

Tablo 1. Katılımcıların cinsiyet ve devlet/özel okul türü açısından betimsel istatistikleri

\begin{tabular}{lll}
\hline Cinsiyet & $\mathbf{N}$ & $\%$ \\
\hline Kadın & 326 & 61.86 \\
Erkek & 201 & 38.14 \\
\hline Okul Türü & $\mathbf{N}$ & $\%$ \\
Devlet & 243 & 46.11 \\
Özel & 284 & 53.89 \\
\hline
\end{tabular}

Katılımcıların; 326'sı kadınken (\%61.86) 201'i erkektir (\%38.14), 243'ü devlet okulunda okurken (\%46.11) 284'ü özel okulda okumaktadır (\%53.89).

\section{Veri Toplama Araçları}

Araştırmada veri toplamak amaciyla; Çocuk ve Ergenlerde Mükemmeliyetçi Öz Sunum Ölçeği, Sosyal Görünüş Kaygısı Ölçeği, Rosenberg Benlik Saygısı Ölçeği - Kısa Form ve Kişisel Bilgi Formu kullanılmıştır.

Kişisel Bilgi Formu: Araştırma kapsamında katılımcılardan bazı kişisel bilgilerin toplanması amacıyla kişisel bilgi formu oluşturulmuştur. Oluşturulan bu formda katılımcıların cinsiyet ve okudukları okulun özel/devlet olma durumuna ilişkin sorular sorulmuştur.

Çocuk ve Ergenlerde Mükemmeliyetçi Öz Sunum Ölçeği: Bu araştırmada, örneklem grubunun mükemmeliyetçi öz-sunum düzeylerini belirlemek amacıyla Hewitt ve diğerleri (2011) tarafından geliştirilen ve Akın ve Akın (2012) tarafından Türkçe'ye uyarlanan “Çocuk ve Ergenlerde 
Mükemmeliyetçi Öz-Sunum Ölçeği" kullanılmıştır. Ölçek 5'li likert tipi bir ölçme aracıdır; 18 maddeden ve 3 alt boyuttan oluşmaktadır. Ölçekte Mükemmeliyetçi Öz-Yükseltme alt boyutuna yönelik 8 madde, Hatanın Gizlenmesi alt boyutuna yönelik 6 madde, Hatanın Söylenmemesi alt boyutuna yönelik ise 4 madde bulunmaktadır. Ölçekte ters puanlanan madde bulunmamaktadır. Ölçeğin alt boyutlarından alınan puanlar yükseldikçe bireyin ilgili boyuta ait mükemmeliyetçi öz-sunuma yüksek düzeyde sahip olduğu söylenebilir. Yüksek puanlar yüksek düzeyde mükemmeliyetçi öz-sunumu göstermektedir (Akın ve Akın, 2012). Ölçeğin Türkçe formunun geçerlik ve güvenirlik çalışmaları Ahmet Akın ve Ümran Akın tarafından yapılmıştır. Yapı geçerliliği için uygulanan ölçeğin yapı geçerliliği için uygulanan doğrulayıcı faktör analizi sonucunda, orijinal formda olduğu gibi tek boyutta uyum verdiği görülmüştür. $\left(x^{2}=193.04\right.$, RMSEA $=.048, \mathrm{NFI}=.92, \mathrm{IFI}=.97, \mathrm{CFI}=.97$, $\mathrm{GFI}=.92$, SRMR=.054). Ölçeğin Cronbach alfa iç tutarlık güvenirlik katsayıları mükemmeliyetçi öz-yükseltme alt boyutu için .85, hatanın gizlenmesi alt boyutu için .65, hatanın söylenmemesi alt boyutu için .82 olarak bulunmuştur. Bu çalışmada ise Cronbach Alpha iç tutarlılık katsayıları mükemmeliyetçi öz-yükseltme alt boyutu için .89, hatanın gizlenmesi alt boyutu için .75, hatanın söylenmemesi alt boyutu için .65 olarak bulunmuştur.

Sosyal Görünüş Kaygısı Ölçeği: Sosyal görünüş kaygısının düzeyini ölçen Sosyal Görünüş Kaygısı Ölçeği'nden alınan yüksek puanlar görünüş kaygısının yüksek olduğuna, düşük puanlar ise düşük olduğunu göstermektedir. Hart ve diğerleri (2008), kişilerin diş görünümleriyle ilgili olarak yasadığı duygusal, bilişsel ve davranışsal kaygıları ölçmek için hazırlanmış bir ölçektir. Doğan (2010) tarafından ölçeğin Türkçe geçerlilik güvenilirlik çalışması yapılmıştır. Türkçe geçerlilik güvenilirlik çalışması 143 kız öğrenci, 197 erkek öğrenci toplamda 340 öğrenci katılmıştır. Ölçeğin geçerliliğini sınamak için Olumsuz Değerlendirilme Korkusu Ölçeği Kısa Formu kullanılmıştır. Analizler, Sosyal Görünüş Kaygısı Ölçeği'nin Türk üniversite öğrencileri üzerinde yeterli düzeyde geçerlilik ve güvenilirlik değerlerine sahip olduğunu göstermiştir (Doğan, 2010). Test-tekrar test güvenirlik katsayısı .85, test yarılama yöntemi kullanılarak hesaplanan güvenirlik 
katsayısı .88, Cronbach Alpha iç tutarlılık katsayısı .93 bulunmuştur. Ölçekten alınabilecek en yüksek puan 80 en düşük puan ise $16^{\prime}$ dır. Ardından yine Doğan (2011) tarafından ölçeğin psikometrik özellikleri, 12-15 yaş aralığında bulunan 235'i kız 218'i erkek olmak üzere toplam 453 ergen üzerinde incelenmiştir ve tek faktörlü bir yapıya sahip olan ölçeğin Ergenler için Sosyal Kaygı Ölçeği ile arasında .76 düzeyinde ilişki olduğu, ölçeğin Cronbach Alpha iç tutarlılık katsayısının .91, tekrar test güvenirlik katsayısının ise .80 olduğu sonucuna ulaşılmıştır. Elde edilen bulgular Sosyal Görünüş Kaygısı Ölçeği'nin ergenlerde kullanılabilmesi için geçerli ve güvenilir bir ölçme aracı olduğunu göstermektedir. Bu çalışmada ise Cronbach Alpha iç tutarlılık katsayısı .93 olarak bulunmuştur.

Rosenberg Benlik Saygısı Ölçeği - Kısa Form: Katılımcıların kendilerine verdikleri değeri ölçmek için literatürde oldukça sik kullanılan Rosenberg Benlik-Saygısı Ölçeği (Kısa Form, 1965)'nin Türk kültürüne uyarlama çalışması Çuhadaroğlu (1986) tarafından gerçekleştirilmiştir. Beş olumlu ve beş olumsuz ifadenin yer aldığ 10 maddelik ölçek 4'lü Likert tipidir. Benlik saygısı tek yönlü bir kavram olarak kabul edildiğinden dolayı toplam puan kullanılmıştır. Çuhadaroğlu (1986) tarafından Türkçe'ye uyarlanan ölçeğin geçerlik ve güvenirlik çalışmaları sonunda benlik saygısı kategorisinin geçerliğini sınamak için psikiyatrik görüşmeler yapılmıştır. Görüşlerden ve benlik saygısı ölçeğinden elde edilen sonuçların arasındaki ilişkiler hesaplanmış ve geçerlik oranı 0.71 olarak hesaplanmıştır. Ölçeğin test-tekrar test güvenirlik katsayısının ise 0.75 olduğu belirtilmiştir (Çeçen, 2008). Bu çalışmada Cronbach Alpha iç tutarlılık katsayısı .85 olarak bulunmuştur.

\section{Verilerin Toplanması}

Araştırma için Necmettin Erbakan Üniversitesi Sosyal ve Beşeri Bilimler Bilimsel Araştırmalar Etik Kurulu'ndan (19.02.2021 tarih ve Karar No: 2021/64) izin alınmıştır. Veriler 2020-2021 Eğitim-Öğretim yılı bahar döneminde toplanmıştır. Verileri toplamak amacıyla öğrenciler, Konya ili merkez ilçelerinde bulunan liselerden amaçlı örnekleme yöntemi olan maksimum çeşitlilik örnekleme yöntemi ile seçilmiştir. Kararlaştırılan 
gün ve saatlerde Çocuk ve Ergenlerde Mükemmeliyetçi Öz Sunum Ölçeği, Sosyal Görünüş Kaygısı Ölçeği ve Rosenberg Benlik Saygısı Ölçeği birlikte uygulanmıştır. Öğrencilerin kişisel bilgilerini elde etmek için de ayrıca Kişisel Bilgi Formu kullanılmıştır. Uygulama yaklaşık olarak 15-30 dakika arasında sürmüştür.

\section{Verilerin Analizi}

Araştırma verileri toplandıktan sonra bilgisayar ortamına aktarılarak analizler için hazır duruma getirilmiştir. Araştırma verilerinin analizinde değişkenlere bağlı olarak SPSS 25.0 paket programı kullanılmıştır. Mükemmeliyetçi öz sunum, sosyal görünüş kaygısı ve benlik saygisı arasındaki ilişkinin analizinde Pearson momentler çarpım korelasyon katsayısı tekniğinden yararlanılmıştır. Sosyal görünüş kaygısı ve benlik saygısının mükemmeliyetçi öz sunumu anlamlı düzeyde yordayıp yordamadığı ise çoklu regresyon analizi tekniği ile hesaplanmıştır. Ayrıca ergenlerin mükemmeliyetçi öz sunumlarının cinsiyet ve özel okulda ya da devlet okulunda okumalarına göre farklılaşıp farklılaşmadığına bakmak için bağımsız gruplar $t$ testi analizinden yararlanılmıştır.

\section{Bulgular}

Bu bölümde araştırmanın amacı ve alt amaçları doğrultusunda toplanan verilerin istatistiksel bulgularına yer verilmiştir. Ergenlerin mükemmeliyetçi öz sunum düzeylerinin cinsiyete göre farklılaşıp farklılaşmadığına ilişkin bağımsız gruplar $\mathrm{t}$ testi sonuçları Tablo 2'de verilmiştir.

Ergenlerin öz yükseltme düzeyleri ile cinsiyetleri arasında anlamlı bir farklılık olup olmadığı yapılan $t$ testi ile analiz sonucunda ergenlerin öz yükseltme düzeyleri ile cinsiyetleri arasında anlamlı bir farklılık bulunmamıştır ( $\mathrm{t}=.861, \mathrm{p}>$.05). Hatanın gizlenmesi düzeyleri ile cinsiyetleri arasında anlamlı bir farklılık olup olmadığı yapılan t testi ile analiz sonucunda ergenlerin hatanın gizlenmesi düzeyleri ile cinsiyetleri arasında anlamlı bir farklılık bulunmamıştır $(\mathrm{t}=-.605, \mathrm{p}>.05)$. Hatanın söylenmemesi düzeyleri ile cinsiyetleri arasında anlamlı bir farklılık olup 
olmadığı yapılan $t$ testi ile analiz sonucunda ergenlerin hatanın söylenmemesi düzeyleri ile cinsiyetleri arasında anlamlı bir farklılık bulunmamıştır $(\mathrm{t}=-.612, \mathrm{p}>.05)$.

Tablo 2. Ergenlerin mükemmeliyetçi öz sunum düzeylerinin cinsiyete göre t-testi sonuçları

\begin{tabular}{lllllll}
\hline Alt Boyutlar & Cinsiyet & $\mathbf{N}$ & $\overline{\mathbf{x}}$ & SS & $\mathbf{t}$ & $\mathbf{p}$ \\
\hline Öz Yükseltme & Kadın & 326 & 20.70 & 6.95 & .861 & .390 \\
& Erkek & 201 & 21.24 & 7.22 & & \\
\hline Hatanın Gizlenmesi & Kadın & 326 & 19.87 & 4.40 & -.605 & .545 \\
& Erkek & 201 & 19.60 & 5.10 & & \\
\hline Hatanın Söylenmemesi & Kadın & 326 & 11.37 & 3.27 & -.612 & .541 \\
& Erkek & 201 & 11.20 & 2.96 & & \\
\hline
\end{tabular}

$p<.05$

Ergenlerin mükemmeliyetçi öz sunum düzeylerinin okul türüne göre farklılaşıp farklılaşmadığına ilişkin bağımsız gruplar $t$ testi sonuçları Tablo 3.'te verilmiştir.

Tablo 3. Ergenlerin mükemmeliyetçi öz sunum düzeylerinin okul türüne göre t-testi sonuçları

\begin{tabular}{|c|c|c|c|c|c|c|}
\hline Alt Boyutlar & Okul Türü & $\mathbf{N}$ & $\bar{x}$ & SS & $t$ & p \\
\hline \multirow{2}{*}{ Öz Yükseltme } & Devlet & 243 & 21.45 & 6.96 & \multirow{2}{*}{1.633} & \multirow{2}{*}{.103} \\
\hline & Özel & 284 & 20.44 & 7.11 & & \\
\hline \multirow{2}{*}{ Hatanın Gizlenmesi } & Devlet & 243 & 20.42 & 4.35 & \multirow{2}{*}{2.977} & \multirow{2}{*}{$.003^{*}$} \\
\hline & Özel & 284 & 19.21 & 4.88 & & \\
\hline \multirow{2}{*}{ Hatanın Söylenmemesi } & Devlet & 243 & 11.49 & 3.40 & \multirow{2}{*}{1.253} & \multirow{2}{*}{.211} \\
\hline & Özel & 284 & 11.14 & 2.93 & & \\
\hline
\end{tabular}

${ }^{*} p<.05$

Ergenlerin öz yükseltme düzeyleri ile okul türü arasında anlamlı bir farklılık olup olmadığı yapılan $t$ testi ile analiz sonucunda ergenlerin öz yükseltme düzeyleri ile okul türü arasında anlamlı bir farklılık bulunmamıştır ( $\mathrm{t}=1.633$, p>.05). Hatanın gizlenmesi düzeyleri ile okul türü arasında anlamlı bir farklılık olup olmadığı yapılan $t$ testi ile analiz sonucunda ergenlerin hatanın gizlenmesi düzeyleri ile okul türü arasında anlamlı bir farklılık bulunmuştur $(\mathrm{t}=2.977, \mathrm{p}<.05)$. Bu bulgudan hareketle, devlet okulundaki öğrencilerin $(\bar{x}=20.42)$ özel okuldaki öğrencilere $(\bar{x}=19.21)$ göre hatanın gizlenmesi düzeylerinin daha yüksek olduğu görülmektedir. Hatanın söylenmemesi düzeyleri ile okul türü 
arasında anlamlı bir farklılık olup olmadığı yapılan $t$ testi ile analiz sonucunda ergenlerin hatanın söylenmemesi düzeyleri ile okul türü arasında anlamlı bir farklılık bulunmamıştır ( $\mathrm{t}=1.253$, $\mathrm{p}>.05)$.

Ergenlerin mükemmeliyetçi öz sunum, benlik saygısı ve sosyal görünüş kaygısı arasındaki ilişkileri incelemek amacıyla ilgili ölçek ve alt boyutlardan elde ettikleri puanlar arasinda hesaplanan korelasyon katsayıları Tablo 4.'te verilmiştir.

Tablo 4. Mükemmeliyetçi öz sunum (MÖS), benlik saygısı ve sosyal görünüş kaygısı arasındaki ilişkiler

\begin{tabular}{lllll}
\hline & \multicolumn{2}{c}{ Benlik Saygısı } & & \multicolumn{2}{c}{ Sosyal Görünüş Kaygisı } \\
\cline { 2 - 5 } & $\mathbf{r}$ & $\mathbf{p}$ & $\mathbf{r}$ & $\mathbf{p}$ \\
\hline MÖS Öz Yükseltme & $\mathbf{- . 1 8 2 ^ { * * }}$ & .000 &. $\mathbf{4 4 9 *}$ & .000 \\
MÖS Hatanın Gizlenmesi & $-.312^{* *}$ & .000 &. $\mathbf{5 4 5 * *}$ & .000 \\
MÖS Hatanin Söylenmemesi & $-.296^{* *}$ & .000 & $.347^{* *}$ & .000 \\
MÖS Toplam & $-.299^{* *}$ & .000 & $\mathbf{5 5 3}^{* *}$ & .000 \\
\hline$* * p<.01$ & & & &
\end{tabular}

Tablo 4.'e bakıldığında mükemmeliyetçi öz sunumun; öz yükseltme alt boyutunun benlik saygisı ile $(r=-.182, \mathrm{p}<.01)$ negatif, sosyal görünüş kaygısı $(\mathrm{r}=.449, \mathrm{p}<.01)$ ile pozitif yönlü; hatanın gizlenmesi alt boyutunun benlik saygısı ile $(\mathrm{r}=-.312, \mathrm{p}<.01)$ negatif, sosyal görünüş kaygısı $(\mathrm{r}=.545$, $\mathrm{p}<.01)$ ile pozitif yönlü; hatanın söylenmemesi alt boyutunun benlik saygısı ile $(\mathrm{r}=-.296, \mathrm{p}<.01)$ negatif, sosyal görünüş kaygısı $(\mathrm{r}=.347, \mathrm{p}<.01)$ ile pozitif yönlü anlamlı bir ilişki bulunmuştur. Mükemmeliyetçi öz sunumun toplam puanının benlik saygısı ile $(r=-.299, \mathrm{p}<.01)$ negatif, sosyal görünüş kaygısı $(\mathrm{r}=.553, \mathrm{p}<.01)$ ile pozitif yönlü anlamlı bir ilişki bulunmuştur.

Ergenlerin benlik saygısının ve sosyal görünüş kaygısının mükemmeliyetçi öz sunumun öz yükseltme alt boyutunu anlamlı düzeyde yordayıp yordamadığını belirlemek amacıyla çoklu regresyon analizi kullanılmış ve sonuçlar Tablo 5.'te verilmiştir.

Tablo 5. incelendiğinde, oluşturulan regresyon modelinin anlamlı olduğu tespit edilmiştir $(F(2-526)=69.906, \mathrm{p}<.001)$. Benlik saygısının ve sosyal görünüş kaygısının mükemmeliyetçi öz sunumun öz yükseltme alt boyutuna ilişkin varyansın \%20.8'ini açıklamaktadır $\left(\mathrm{R}^{2}=.208\right)$. Standardize edilmiş regresyon katsayısına $(\beta)$ göre, yordayıcı 
değişkenlerin öz yükseltme üzerindeki göreli önem sırası; sosyal görünüş kaygısı ve benlik saygısıdır.

Tablo 5. Ergenlerin benlik saygısının ve sosyal görünüş kaygısının mükemmeliyetçi öz sunumun öz yükseltme alt boyutunu yordamasına ilişkin çoklu regresyon analizi sonuçları

\begin{tabular}{llllll}
\hline Model & B & SH & $\beta$ & $\mathbf{t}$ & $\mathbf{p}$ \\
\hline Sabit & 12.885 & 1.518 & & 8.485 & .000 \\
Benlik Saygisı & .001 & .038 & .001 & .027 & .979 \\
Sosyal Görünüş KaygıS1 & .185 & .015 & .546 & 12.194 & .000 \\
\hline$R=.545$ & $R^{2}=.294$ & & $F_{(2-526)}=110.711$ & & $p=.000$ \\
\end{tabular}

Regresyon katsayılarının anlamlılığına ilişkin sonuçlar incelendiğinde ise sosyal görünüş kaygısı $(\beta=.515, \mathrm{t}=10.854, \mathrm{p}<.001)$ ve benlik saygısının $(\beta=.114, \mathrm{t}=2.397, \mathrm{p}<.05)$ öz yükseltme üzerinde önemli (anlamli) bir yordayıcı olduğu görülmektedir.

Ergenlerin benlik saygısının ve sosyal görünüş kaygısının mükemmeliyetçi öz sunumun hatanın gizlenmesi alt boyutunu anlamlı düzeyde yordayıp yordamadığını belirlemek amacıyla çoklu regresyon analizi kullanılmış ve sonuçlar Tablo 6.'da verilmiştir.

Tablo 6. Ergenlerin benlik saygısının ve sosyal görünüş kaygısının mükemmeliyetçi öz sunumun hatanın gizlenmesi alt boyutunu yordamasına ilişkin çoklu regresyon analizi sonuçları

\begin{tabular}{llllll}
\hline Model & B & SH & $\boldsymbol{\beta}$ & $\mathbf{t}$ & $\mathbf{p}$ \\
\hline Sabit & 6.899 & 2.426 & & 2.844 & .005 \\
Benlik Saygıs1 & .144 & .060 & .114 & 2.397 & .017 \\
Sosyal Görünüş Kaygis1 & .263 & .024 & .515 & 10.854 & .000 \\
\hline$R=.459 \quad R^{2}=.208$ & & $F_{(2-526)=69.906}$ & & $p=.000$ & \\
\hline
\end{tabular}

Tablo 6. incelendiğinde, oluşturulan regresyon modelinin anlaml olduğu tespit edilmiştir $\left(F_{(2-526)}=110.711, \mathrm{p}<.001\right)$. Benlik saygısının ve sosyal görünüş kaygısının mükemmeliyetçi öz sunumun hatanın gizlenmesi alt boyutuna ilişkin varyansın \%29.4'ünü açıklamaktadır $\left(R^{2}=.294\right)$. Standardize edilmiş regresyon katsayısına $(\beta)$ göre, yordayıcı değişkenlerin hatanın gizlenmesi üzerindeki göreli önem sırası; sosyal görünüş kaygısı ve benlik saygısıdır. Regresyon katsayılarının anlamlılığına ilişkin sonuçlar incelendiğinde ise sosyal görünüş kaygısının $(\beta=.546, \mathrm{t}=12.194, \mathrm{p}<.001)$ hatanın gizlenmesi üzerinde önemli 
(anlamlı) bir yordayıcı olduğu görülmektedir. Benlik saygısı $(\beta=.001$, $\mathrm{t}=.027, \mathrm{p}>.05$ ) ise önemli bir etkiye sahip değildir.

Ergenlerin benlik saygısının ve sosyal görünüş kaygısının mükemmeliyetçi öz sunumun hatanın söylenmemesi alt boyutunu anlamlı düzeyde yordayıp yordamadığını belirlemek amacıyla çoklu regresyon analizi kullanılmış ve sonuçlar Tablo 7.'de verilmiştir.

Tablo 7. Ergenlerin benlik saygısının ve sosyal görünüş kaygısının mükemmeliyetçi öz sunumun hatanın söylenmemesi alt boyutunu yordamasına ilişkin çoklu regresyon analizi sonuçları

\begin{tabular}{|c|c|c|c|c|c|}
\hline Model & B & SH & $\beta$ & $t$ & p \\
\hline Sabit & 11.498 & 1.136 & & 10.118 & .000 \\
\hline Benlik Saygısı & -.082 & .028 & -.145 & -2.914 & .004 \\
\hline Sosyal Görünüş Kaygisı & .060 & .011 & .264 & 5.316 & .000 \\
\hline $\begin{array}{ll}R=.367 & R^{2}=.131 \\
\end{array}$ & & $F_{(2-526)}=$ & & $p=.000$ & \\
\hline
\end{tabular}

Tablo 7. incelendiğinde, oluşturulan regresyon modelinin anlamlı olduğu tespit edilmiştir $\left(F_{(2-526)}=40.719, \mathrm{p}<.001\right)$. Benlik saygısının ve sosyal görünüş kaygısının mükemmeliyetçi öz sunumun hatanın söylenmemesi alt boyutuna ilişkin varyansın \%13.1'ini açıklamaktadır $\left(\mathrm{R}^{2}=.131\right)$. Standardize edilmiş regresyon katsayısına $(\beta)$ göre, yordayıcı değişkenlerin hatanın söylenmemesi üzerindeki göreli önem sırası; sosyal görünüss kaygısı ve benlik saygısıdır. Regresyon katsayılarının anlamlılığına ilişkin sonuçlar incelendiğinde ise sosyal görünüş kaygısı $(\beta=.264, \mathrm{t}=5.316, \mathrm{p}<.001)$ ve benlik saygisinin $(\beta=-.145, \mathrm{t}=-2.914, \mathrm{p}<.01)$ hatanın söylenmemesi üzerinde önemli (anlamlı) bir yordayıcı olduğu görülmektedir.

\section{Tartışma}

Araştırma sonuçları incelendiğinde, ergenlerin mükemmeliyetçi öz sunumun üç alt boyutu olan mükemmeliyetçi öz yükseltme, hatanın gizlenmesi ve hatanın söylenmemesi düzeylerinin cinsiyete göre anlamlı bir şekilde farklılaşmadığı tespit edilmiştir. Literatür incelendiğinde, yapılan birçok araştırmada mükemmeliyetçi öz sunum düzeylerinin cinsiyete göre farklılaşmadığı tespit edilmiştir (Özyürek, Özkan, Belge ve Yavuz, 2019; Ceylan, 2017; Bingöl, 2018; Zeifman, Atkey, Young, Flett, 
Hewitt ve Goldberg, 2015; Flett, Galfi-Pechenkov, Molnar, Hewitt ve Goldstein, 2012; Hewitt vd., 2011; Hewitt, Caelian, Flett, Sherry, Collins ve Flynn, 2002). Bu çalışmalarda alınan sonuçlar araştırma sonuçlarımızı destekler niteliktedir. Literatürde sadece iki çalışmada mükemmeliyetçi öz sunumun cinsiyete göre farklılaştığı görülmektedir. Stoeber ve Roche (2014), yaptıkları araştırmada kız ergenlerin mükemmeliyetçi öz sunum düzeylerini erkeklerden daha yüksek bulmuştur. Uzunel (2016) ise erkek ergenlerin mükemmeliyetçi öz sunum düzeylerini kılara göre daha yüksek bulmuştur. Ergenlerde mükemmeliyetçi öz sunum düzeyinin cinsiyete göre farklılaşmaması ergenlik döneminin hayali seyirci kavramı ile açıklanabilir. Hayali seyircinin genel özelliği olarak ergen birey başkaları tarafından izlendiğini ve değerlendirildiğini düşünmektedir (Vartanian, 2000). Başkaları tarafından izlendiğini düşünen ergen, kendisinde bir olumsuzluk görüyorsa diğer insanların da bunu göreceğini düşünebilir ve kusurlarını gizlemek için çabalayabilir. Bu yüzden, dışarıya en iyi şekilde görünmek için çabalayabilir. Buradan hareketle mükemmeliyetçi öz sunumun, ergenlik döneminin ortak özelliklerini barındırdığı ve bundan dolayı cinsiyete göre farklılaşmadığı söylenebilir.

Araştırma sonuçlarına göre, ergenlerde mükemmeliyetçi öz sunumun alt boyutları olan mükemmeliyetçi öz yükseltme ve hatanın söylenmemesinin özel okulda veya devlet okulunda okuma durumuna göre farklılaşmadığı görülmüştür. Hatanın gizlenmesi alt boyutuna bakıldığında devlet okulunda okuyan öğrencilerin hatanın gizlenmesi düzeylerinin özel okulda okuyan öğrencilere göre daha yüksek olduğu tespit edilmiştir. Literatür incelendiğinde ergenlerin mükemmeliyetçi öz sunum düzeylerinin devlet okulunda veya özel okulda okumalarına göre farklılaşıp farklılaşmadığını araştıran bir çalışmaya rastlanmamıştır. Hatanın gizlenmesi, kusurlu görünmenin ve mükemmel olmayan davranışların engellenmesini, ortaya çıkabilecek hataların diğer insanlardan gizlenmesini ve bunun için gösterilen tüm çabaları içerir (Hewitt vd., 2003). Bu çaba ile mükemmeliyetçi bir kişinin diğerleri tarafından onaylanmama düzeyinin azaltılması amaçlanmaktadır (Nelson, 2008). Özel okulda okuyan öğrencilerin yaşam koşulları, yetiştikleri çevre ve girdikleri eğitim ortamı düşünüldüğünde diğer insanlar tarafından daha kolay onay alabildikleri ve bu yüzden kusurlu 
görünmekten daha az çekindikleri yorumu yapılabilir. Hançer ve Tüfekçi (2016), yaptıkları araştırmada özel okulda okuyan öğrencilerin benlik saygılarının devlet okulunda okuyan öğrencilere göre daha yüksek olduğunu tespit etmiştir. Hatanın gizlenmesi ve benlik saygısı arasında negatif yönlü bir ilişki olduğu düşünüldüğünde (McGee, 2007), devlet okulundaki öğrencilerin özel okuldaki öğrencilere göre benlik saygılarının daha düşük olmasından dolayı hatanın gizlenmesi düzeylerinin yüksek olduğu yorumu yapılabilir.

Ergenlerin mükemmeliyetçi öz sunum düzeyleri ile sosyal görünüş kaygıları arasındaki ilişki incelendiğinde, araştırma sonuçlarına göre ergenlerde mükemmeliyetçi öz sunumun alt boyutlarının her birinin sosyal görünüş kaygısı ile orta düzeyde pozitif yönlü anlamlı bir ilişkisi bulunmuştur. Heller (2013) tarafından yapılan araştırmada mükemmeliyetçi öz sunumun tüm alt boyutları ve sosyal görünüş kaygısı arasında pozitif yönlü bir ilişki tespit edilmiştir ve bu araştırma sonuçlarımızla örtüşmektedir. Literatür incelendiğinde mükemmeliyetçi öz sunum ve sosyal görünüş kaygısının birlikte ele alındığ çok fazla çalışma olmadığı görülmektedir. Fakat mükemmeliyetçi öz sunumla ilişkisi olan mükemmeliyetçilik kavramı ile sosyal görünüş kaygısı arasındaki ilişkilerin incelendiği çalışmalar mevcuttur. Mükemmeliyetçilik ve mükemmeliyetçi öz sunum arasında pozitif yönlü anlamlı ilişkiler bulunmuştur (Hewitt ve Flett, 1991b; Hewitt vd., 2003; Mushquash ve Sherry, 2012). Buna bağlı olarak literatüre bakıldığında Kang, Johnson ve Kim'in çalışmasında (2013) mükemmeliyetçiliğin artması ile sosyal görünüş kaygısının da artacağı yönündeki bulgular yer almaktadır. Sosyal görünüş kaygısı yaşayan bireylerin, görünüşlerindeki kusuru kamufle etmek için buna uygun kıyafet tercihi yapma eğiliminde oldukları yorumu yapılabilir (Kang, Johnson ve Kim, 2013). Mükemmeliyetçilik ve sosyal görünüş kaygısı arasında yapılan çalışmalara bakıldığında mükemmeliyetçilik ve sosyal görünüş kaygısı arasında pozitif yönlü anlamlı bir ilişki olduğu görülmektedir (Levinson vd., 2013; Arslan, Oral ve Karababa, 2018; Çelik ve Şenay Güzel 2018). Sosyal görünüş kaygısının artması, bireyin kendine daha çok odaklanmasına ve mükemmeliyetçilik düzeyinin yükselmesine sebep olabilmektedir (Çelik ve Şenay Güzel, 2018). Bu araştırmalar, araştırma 
sonucumuzu destekler niteliktedir. Araştırma sonuçlarının aksini gösteren bir çalışma tespit edilememiştir.

Ergenlerin mükemmeliyetçi öz sunum düzeyleri ile benlik saygıları arasındaki ilişkiye bakıldığında, araştırma sonuçlarına göre ergenlerde mükemmeliyetçi öz sunumun alt boyutlarının her birinin benlik saygısı ile negatif yönlü anlamlı bir ilişkisi bulunmuştur. İlgili literatür incelendiğinde mükemmeliyetçi öz-sunum ve benlik saygısı arasında negatif yönlü bir ilişki olduğunu gösteren araştırmalar bulunmaktadır (Hewitt ve Flett 1993; Hewitt, Flett ve Ediger, 1995; Hewitt vd., 2003). Hewitt ve diğerleri (2003), yaptıkları çalışma sonrasında mükemmeliyetçi öz sunum ve düşük benlik saygısı arasındaki ilişkiye vurgu yaparak, mükemmeliyetçi öz sunumu; düşük benlik saygısı, kişisel ve kişilerarası sıkıntı gibi üç yön ile ilişkili olan, öz-sunumun uyumsuz, yanıltıcı ve uç bir formu olarak tanımlamıştır. McGee (2007) ise yaptığ1 çalışmada, mükemmeliyetçiliğin anorektik düşüncelerle ve benlik saygısı ile sıkıca ilişkili olduğunu belirtmiştir. Bu araştırmalar araştırma sonucumuzu desteklemektedir.

Hewitt, Flett ve Ediger (1995) mükemmeliyetçi öz sunumu, başkalarına mükemmel bir imaj gösterme ya da benlikteki kusurları ifşa etmekten kaçınma gereksinimi ile ifade etmiştir. Kişinin benliğinde gördüğü kusurları saklama çabasına girmesi ve başkalarına mükemmel bir imaj sunma çabası kendi bedenine ait bir değerlendirme ile başlayabilir. Moe'ya (1999) göre beden imajı, kişinin kendi dış görünüşü hakkında zihninde oluşturduğu bir resmi ifade etmektedir. Doğan (2010) ise kişinin beden algısının olumsuz olmasına bağlı olarak yaşadığı anksiyeteyi sosyal görünüş kaygısı olarak tanımlamaktadır. Araştırma sonuçları ve literatür dikkate alındığında, birey beden imajının olumsuz olmasına bağlı olarak yaşadığı sosyal görünüş kaygısıyla, bedeninde gördüğü kusurları gizleyebilir ve hissettiğinin aksi bir şekilde kendini mükemmel gibi gösterebilir. Özkan (1994), bireyin komplike bir şekilde kendisini yargılaması ve değerlendirmesi neticesinde varmış olduğu kendiliğini kabullenmesi ve bunun sonucunda ulaşılan beğenme durumunu benlik saygısı olarak tanımlamaktadır. Kendisini her anlamda değerlendirdikten sonra ulaştı̆̆ı kendiliği beğenen yani benlik saygısı yüksek olan bireyin, sosyal görünüş kaygısı yaşama ihtimalinin ve mükemmeliyetçi öz sunum düzeyinin de düşük olacağı; benlik 
saygısı düşük olan bireyin ise sosyal görünüş kaygısı yaşama ihtimalinin ve mükemmeliyetçi öz sunum düzeyinin de yüksek olacağı şeklinde bir değerlendirme yapılabilir.

Araştırma sonuçları incelendiğinde, ergenlerin sosyal görünüş kaygıları ve benlik saygılarının mükemmeliyetçi öz sunumun mükemmeliyetçi öz yükseltme ve hatanın söylenmemesi alt boyutlarını yordadığ 1 görülmektedir. Bununla birlikte ergenlerin sosyal görünüş kaygılarının mükemmeliyetçi öz sunumun hatanın gizlenmesi alt boyutunu yordadığı görülürken, benlik saygılarının hatanın gizlenmesi alt boyutu üzerinde bir etkisinin olmadığı görülmektedir. Literatür incelendiğinde sosyal görünüş kaygısı ve benlik saygısının mükemmeliyetçi öz sunumu yordayıp yormadığına dair herhangi bir çalışmaya rastlanamamıştır. Mükemmeliyetçilik ile ilgili literatüre bakıldığında, benlik saygısının mükemmeliyetçiliği yordadığını gösteren çalışmalar mevcuttur (Uçar, 2012; Ashby ve Rice, 2002; Dunkley ve Blankstein, 2000). Bu çalışmalardan alınan sonuçlar araştırmamızın sonuçlarını desteklemektedir. Sosyal görünüş kaygısının mükemmeliyetçi öz sunumu yordamasına dair ise literatürde herhangi bir çalışmaya rastlanmamıştır.

Ergenlik döneminde birey kendi bedenine dönük bir hal almakta ve görünüşünü fazlasıyla önemsemektedir. Görünüşüne dair kaygılanan ergenin, etrafındaki herkesin kendisini izlediği düşüncesine kapılarak, girdiği her ortamda gözleri üzerinde hissederek bir anksiyete yaşayabilir. Doğan (2010), sosyal görünüş kaygısını, bireyin beden algısının olumsuz olmasına bağlı olarak yaşadığı anksiyete olarak tanımlamaktadır. Hewitt, Flett ve Ediger (1995) mükemmeliyetçi öz sunumu, başkalarına mükemmel bir imaj gösterme ya da benlikteki kusurları ifşa etmekten kaçınma gereksinimi ile ifade etmiştir. Bu bağlamda araştırma sonuçları değerlendirildiğinde, bireyin yaşadığı sosyal görünüş kaygısı, kusurlarını gizlemek ve görünüşüne dair bir sorun olmadığını dışarıya göstermek amacıyla mükemmeliyetçi öz sunum düzeyini yükseltmektedir yorumu yapılabilir. Benlik saygısı, bireyin kendini algılama, beğenme ve değerli olduğunu düşünme derecesi olarak açılanmaktadır (Hamarta vd., 2009). Buradan hareketle bireyin kendini olduğu gibi kabullenerek değerli olduğunu düşünme derecesi onun benlik saygısının düzeyini de ortaya koyacaktır. Kendine 
dair değerlendirme yapan bireyin bu değerlendirme sonrasında ulaştığ1 sonuç olumsuz olursa, benlik saygısı düşük olacaktır. Hewitt ve diğerleri (2003), mükemmeliyetçi öz sunumu tanımlarken düşük benlik saygısı ile ilişkisine vurgu yapmışlardır. Bu yüzden, kendine dair yaptığ değerlendirmeden memnun olmayan düşük benlik saygısına sahip bireyin, diğer insanların gözünde daha iyi bir noktaya gelmek için kendini mükemmelmiş gibi tanıtması beklenebilir.

\section{Sonuç ve Öneriler}

Araştırma sonuçlarına göre, ergenlerin mükemmeliyetçi öz sunum düzeyleri, mükemmeliyetçi öz sunumun üç alt boyutunda da cinsiyete göre farklılaşmamaktadır. Araştırma sonuçlarına göre, devlet okulunda okuyan ergenler, özel okuldaki ergenlere göre hatalarını gizlemeye daha fazla meyilllidir. Mükemmeliyetçi öz yükseltme ve hatanın söylenmemesi alt boyutları ise okul türüne göre (özel-devlet) farklılaşmamaktadır. Ergenlerin mükemmeliyetçi öz sunum düzeyleri ile sosyal görünüş kaygıları arasında pozitif yönde orta düzeyde anlamlı bir ilişki görülmüştür. Ergenlerin mükemmeliyetçi öz sunum düzeyleri ile benlik saygıları arasında negatif yönde orta düzeyde anlamlı bir ilişki vardır. Ergenlerin sosyal görünüş kaygıları ve benlik saygıları, mükemmeliyetçi öz sunumun mükemmeliyetçi öz yükseltme alt boyutunu anlamlı bir şekilde yordamaktadır. Ergenlerin sosyal görünüş kaygıları, mükemmeliyetçi öz sunumun hatanın gizlenmesi alt boyutunu anlamlı bir şekilde yordamaktadır. Benlik saygısı ise hatanın gizlenmesi alt boyutu üzerinde önemli bir etkiye sahip değildir. Ergenlerin sosyal görünüş kaygıları ve benlik saygıları, mükemmeliyetçi öz sunumun hatanın söylenmemesi alt boyutunu anlamlı bir şekilde yordamaktadır.

Araştırmada elde edilen sonuçlar ışığında aşağıdaki önerilere yer verilmiştir:

- Mükemmeliyetçilik, mükemmeliyetçi öz sunum, sosyal görünüş kaygısı kavramları ile ilgili velileri ve öğretmenleri bilgilendirici seminerler/eğitimler düzenlenebilir ve ergenlik döneminde bu kavramların öneminden bahsedilebilir.

- Sosyal görünüş kaygısının ergenler üzerindeki etkileri düşünüldüğünde, sosyal görünüş kaygısını azaltmaya ve beden 
algısını olumluya çevirmeye dönük etkinlikler arttırılabilir. Bedeni kabulü öne çıkaran, empati temelli çalışma grupları oluşturulabilir, bedene dair yaşanan kaygıların grubun evrensellik ilkesi ile azaltılması sağlanabilir. Ayrıca öğrencilerin ön planda olduğu "idealleştirilen bedenler" temalı tiyatro oyunları uygulanabilir.

- Okullarda benlik saygısını arttıracak etkinliklere tüm derslerde yer verilmesi ve öğretmenlere bu konularda eğitim verilmesi önerilmektedir. Okul psikolojik danışmanları tarafından ilk etapta öğretmenlere benlik saygısının ve öneminin tanıtıldığ 1 seminerler verilirken bununla birlikte benlik saygısını artıracak yaklaşımlar öğretilebilir. Daha sonra derslerde ortak zamanlı olacak şekilde "benlik saygısını artıracak yaklaşımlar" sergilenebilir. Örneğin, biyoloji dersinde tüm öğrencilerin bedenlerinin güçlü ve olumlu yönlerini keşfetmesi ve bunların ön plana çıarılması sağlanırken, matematik dersinde her öğrenciye başarılı olduğunu hissedebileceği bir görev verilebilir. Tüm bunların zincir şeklinde işlediği bir düzen oluşturulabilir. 


\title{
EXTENDED ABSTRACT
}

\section{The Relationship Between Adolescents Perfectionistic Self-Presentation Levels and Social Appearance Anxiety and Self-Esteem}

\author{
Ahmet Koçyiğit- Ali Fuat Yalçın \\ Necmettin Erbakan University
}

Adolescence is a period in which the individual begins to gain identity. This period starts in the secondary school period and continues at the high school level. With adolescence, the individual gets involved in a more social environment, and his peer influence increases even more. Adolescence is a period in which the body image and appearance of the individual gains a lot of importance. In this process, an individual's desire to look perfect may arise in order to eliminate the possibility of rejection while reflecting oneself in social environments. This desire to be perfect can manifest itself in the form of perfectionism and perfectionist self-presentation. Perfectionist self-presentation has been defined by Hewitt and Flett (1993) as a theoretical structure that manifests itself with behaviors of showing oneself to others as perfect and avoiding the appearance of imperfection. Perfectionist self-presentation has three subdimensions: self-enhancement, hiding the error, and not stating the error. Perfectionist self-enhancement is the counterpart to a style of selfpresentation that expresses a person's need to present himself to others as if he is perfect. Hiding the error consists of elements that reflect the anxiety experienced about the obvious appearance of imperfect behavior. It includes the prevention of imperfection and imperfect behavior, hiding the mistakes that may arise from other people, and all efforts made for this. Not saying the error reflects the need to avoid disclosing or admitting the error or defect. While avoiding the admission of errors and defects, there is a situation where the resulting errors and defects are not accepted.

Looking at the perfectionist self-presentation concept, the individual's effort to show himself / herself perfectly against people in the social environment stands out. Behaviors such as trying to show himself better 
than he is, avoiding activities he can make mistakes and not expressing his existing mistakes, denial; It is about the individual wanting to make a good impression on the individuals he / she communicates with. While individuals want to introduce themselves to another person, they sometimes doubt their own qualities in terms of leaving the impression and impact they want on other people. When such a situation occurs, individuals are likely to experience social anxiety (Leary and Kowalski, 1995). Social appearance anxiety, which is a type of social anxiety, is defined as the state of tension and anxiety that individuals feel while evaluating their physical appearance by others (Hart et al., 1989). Body image is important because it affects one's self-esteem. While high selfesteem is associated with positive body image, low self-esteem is associated with negative body image (Jung and Lee, 2006).

There is a fear of rejection that the individual experiences with the desire to be accepted in social situations. As the individual returns to his own body, he begins to make evaluations about his body image. As a result of these evaluations, he gets positive or negative results about his appearance. While individuals with positive results are expected to have high self-esteem, individuals with negative results are expected to have low self-esteem. Considering the literature information, individuals with high self-esteem should experience less appearance anxiety because they make a positive evaluation of their appearance, and as a result, they should reflect themselves less in a perfectionist way. Likewise, individuals with low self-esteem are expected to experience more appearance anxiety and, as a result, to present themselves in a more perfectionist way due to their negative evaluation of their appearance. The accuracy of this information has been questioned for the purpose of this research.

In this study, the relationship between perfectionist self-presentation levels of high school students and their social appearance anxiety and self-esteem was examined. The study also aimed to reveal whether the perfectionist self-presentation differs according to gender and type of school (private / state) variables. The study group of the study consists of 527 high school students who were selected by the maximum diversity sampling method, which is the purposeful sampling method, according to the gender of the high school students in the central districts of Konya 
province in 2020-2021, and their reading at the public school or private school. The "Personal Information Form" was used to determine the gender and reading status of the participants in private or public school. In order to determine the perfectionist self-presentation levels of the individuals participating in the study, the "Perfectionist SelfPresentation Scale in Children and Adolescents" developed by Hewitt et al. (2011) and adapted into Turkish by Akın and Akın (2012) was used. In order to determine the social appearance anxiety of the participants, the "Social Appearance Anxiety Scale", which was developed by Hart et al. (2008) and adapted into Turkish by Doğan (2010) and later determined by Doğan (2011) through validity and reliability studies on adolescents, was used. In order to measure the self-esteem of the research participants, the "Rosenberg Self-Esteem Scale-Short Form" developed by Rosenberg (1965) and adapted to Turkish culture by Çuhadaroğlu (1986) was used. In the analysis of the data, Pearson Product Moments Correlation Coefficient was used to reveal the relationship between variables, Multiple Regression Analysis to determine the predictive relationships between the relevant variables, and the $\mathrm{T}$ Test to examine the relevant variables in terms of demographic information. According to the results of the study, a moderately significant positive relationship was found between perfectionist selfpresentation and social appearance anxiety. A moderately significant negative correlation was found between perfectionist self-presentation and self-esteem. It was observed that social appearance anxiety and selfesteem predicted perfectionist self-presentation. According to these relationships, the higher the self-esteem of the individual, the lower the perfectionist self-presentation level, and the higher the social appearance anxiety, the higher the perfectionist self-presentation level. The conclusion that the hiding error sub-dimension of perfectionist selfpresentation differs significantly among students studying in public school compared to those studying in private school, but the other subdimensions do not differ according to school type. It was observed that the three sub-dimensions of perfectionist self-presentation did not differ according to gender. 


\section{Kaynakça / References}

Adams, J. F. (1995). Ergenliği anlamak (Çev. B. Onur). Ankara: İmge Kitapevi.

Akın, A. ve Akın, U. (2012). Turkish version of the perfectionistic selfpresentation in children andadolescents scale. The International Counseling and Education Conference 2012 (ICEC 2012). May, 3-5, İstanbul, Turkey.

Arslan, C., Oral, T. ve Karababa, A. (2018). Ortaokul öğrencilerinin umut düzeylerinin, kaygı, depresyon ve mükemmeliyetçilik açısından incelenmesi. Eğitim ve Bilim, 43(194), 101-110. Doi: 10.15390/EB.2018.6592

Ashby, J. S. and Rice, K. G. (2002). Perfectionism, dysfunctional attitudes, and self-esteem: A structural equations analysis. Journal of Counseling $\mathcal{E}$ Development, 80(2), 197-203.

Bingöl, T. Y. (2018). Ergenlerin öz-yeterlik ve mükemmeliyetçi öz-sunum düzeyleri arasındaki ilişkinin incelenmesi. Yaşam Becerileri Psikoloji Dergisi, 2(4), 223-232.

Cash, T. F. and Pruzinsky, T. (1990). Body image: A handbook of theory, research, and clinical practice. New York: Guilford Press.

Cash, T. F. and Fleming E. C. (2002). The impact of body image experiences: Development of the body image quality of life inventory. Journal of Eating Disorder, 31, 455-60.

Ceylan, A. (2017). Ergenlerde mükemmeliyetçi benlik sunumunun özgüven ile ilişkisi. (Yüksek Lisans Tezi). İstanbul Gelişim Üniversitesi, Sosyal Bilimler Enstitüsü, İstanbul.

Çeçen, R. A. (2008). Üniversite öğrencilerinde yaşam doyumunu yordamada bireysel bütünlük (tutarlılık) duygusu, aile bütünlük duygusu ve benlik saygisı. Eğitimde Kuram ve Uygulama, 4(1), 19-23.

Çelik, E. ve Şenay Güzel, H. (2018). Ergenlerde sosyal görünüş kaygısı ile mükemmeliyetçilik arasındaki ilişki: Benlik saygısının aracı rolü. Journal of Turkish Educational Sciences, 16(2), 235-256.

Çetinkaya, B. ve Başbakkal, Z. (2005). Çocuk sağlığı ve hastalıkları kliniklerinde çalışan hemşirelerin benlik saygısı düzeylerinin ve çocuk yetiştirme tutumlarının incelenmesi. Ege Üniversitesi Hemşirelik Yüksekokulu Dergisi, 21(2), 47-57.

Çuhadaroğlu, F. (1986). Adolesanlarda benlik saygısı. (Yayınlanmamış Tipta Uzmanlık Tezi). Hacettepe Üniversitesi, Tıp Fakültesi, Psikiyatri Anabilim Dalı, Ankara. 
Doğan, T. (2010). Sosyal görünüş kaygısı ölçeğinin Türkçeye uyarlaması geçerlilik ve güvenilirlik çalışması. Hacettepe Üniversitesi Ĕ̆itim Fakültesi Dergisi, 39,151- 159.

Doğan, T. (2011). Sosyal Görünüş Kaygısı Ölçeği'nin psikometrik özelliklerinin ergenlerden oluşan bir örneklemde incelenmesi. İlköğretim Online, 10(1), 12-19.

Dunkley, D. M. and Blankstein, K. R. (2000). Self-critical perfectionism, coping, hassles, and current distress: A structural equation modeling approach. Cognitive Therapy and Research, 24(6), 713-730.

Flett, G. L., Galfi-Pechenkov, I., Molnar, D. S., Hewitt, P. L. and Goldstein, A. L. (2012). Perfectionism, mattering, and depression: A mediational analysis. Personality and Individual Differences, 52(7), 828-832.

Hamarta, E., Arslan, C., Saygın, Y. ve Özyeşil, Z. (2009). Benlik saygıSı ve akılcı olmayan inançlar bakımından üniversite öğrencilerinin stresle başa çıkma yaklaşımlarının analizi. Değerler Ĕ̆itimi Dergisi, 7(18), 2542.

Hançer, A. H. ve Tüfekçi, Z. (2016). Ortaokul 8. sınıf öğrencilerinin benlik saygisı düzeylerinin incelenmesi. Cumhuriyet International Journal of Education, 5(4), 31.

Hart, E. A., Leary, M. R. and Rejeski, W. J. (1989). The measurement of social physique anxiety. Journal of Sport and Exercise Psychology, 11, 94-104.

Hart, T. A., Flora, D. B., Palyo, S. A., Fresco, D. M., Holle, C. and Heimberg, R. G. (2008). Development and examination of the social appearance anxiety scale. Assessment, 15(1), 48-59.

Heller, E. A. (2013). Differences between appearance anxiety, perfectionistic selfpresentation, and patterns of disordered eating among female aesthetic athletes. (Doctoral Dissertation). Northern Illinois University.

Hewitt, P. L. and Flett, G. L. (1991b). Perfectionism in the self and social contexts: Conceptualization, assessment, and association with psychopathology. Journal of Personality and Social Psychology, 60(3), 456-470.

Hewitt, P. L. and Flett, G. L. (1993). Dimensions of perfectionism, daily stress, and depression: A test of the specific vulnerability hypothesis. Journal of Abnormal Psychology, 102(1), 58. 
Hewitt, P. L., Flett, G. L. and Ediger, E. (1995). Perfectionism traits and perfectionistic self-presentation in eating disorder attitudes, characteristics, and symptoms. International Journal of Eating Disorders, 18, 317-326.

Hewitt, P. L., Caelian, C. F., Flett, G. L., Sherry, S. B., Collins, L. and Flynn, C. A. (2002). Perfectionism in children: Associations with depression, anxiety, and anger. Personality and Individual Differences, 32(6), 10491061.

Hewitt, P. L., Flett, G. L., Sherry, S. B., Habke, M., Parkin, M., Lam, R. W. and Stein, M. B. (2003). The interpersonal expression of perfection: Perfectionistic self-presentation and psychological distress. Journal of Personality and Social Psychology, 84(6), 1303.

Hewitt, P. L., Blasberg, J. S., Flett, G. L., Besser, A., Sherry, S. B., Caelian, C. and Birch, S. (2011). Perfectionistic self-presentation in children and adolescents: Development and validation of the perfectionistic selfpresentation scale - junior form. Psychological Assessment, 23(1), 125.

Jung, J. and Lee, S. (2006). Cross-cultural comparisons of appearance selfschema, body image, self-esteem, and dieting behavior between Korean and U.S. women. Family and Consumer Sciences Research Journal, 34, 350-365.

Kang, J. Y. M., Johnson, K. K. P. and Kim, J. (2013). Clothing functions and use of clothing to alter mood. International Journal of Fashion Design, Technology and Education, 6(1), 43-52. doi:10.1080/17543266.2012.762428.

Karadağ, G., Güner, İ., Çuhadar, D. ve Uçan, Ö. (2008). Gaziantep Üniversitesi Hemşirelik Yüksekokulu öğrencilerinin benlik saygıları. Fırat Sağllk Hizmetleri Dergisi, 3(7), 29-42.

Karakuş, Ö. ve Kılıç, M. (2016). Üniversite öğrencilerinin sosyal görünüş kaygıları ile benlik saygıları ve yalnızlık düzeyleri arasındaki ilişkinin incelenmesi. Journal of Human Sciences, 13(3), 3838-3841.

Karasar, N. (2016). Bilimsel araştırma yöntemi. Ankara: Nobel Akademik Yayıncilik.

Leary, M. R., Tambor, E. S., Terdal, S. K. and Downs, D. L. (1995). Self-esteem as an interpersonal monitor: The sociometer hypothesis. Journal of Personality and Social Psychology, 68(3), 518. doi:10.1037/00223514.68.3.518. 
Levinson, C. A., Rodebaugh, T. L., White, E. K., Menatti, A. R., Weeks, J. W., Iacovino, J. M. and Warren, C. S. (2013). Social appearance anxiety, perfectionism, and fear of negative evaluation. Distinct or shared risk factors for social anxiety and eating disorders? Appetite, 67, 125-133.

McGee, B. J. (2007). Perfectionism, social exclusion, and anorexia nervosa symptoms. (Doctoral Dissertation). University of British Columbia.

Moe, B. (1999). Understanding the causes of a negative body image. New York: The Rozen Publishing Group.

Mushquash, A. R. and Sherry, S. B. (2012). Understanding the socially prescribed perfectionist's cycle of self-defeat: A 7-day, 14-occasion daily diary study. Journal of Research in Personality, 46(6), 700-709.

Nelson, S. L. (2008). Perfectionism and contingent self-worth in adolescents. (Doctoral Dissertation). Walden University.

Özcan, H., Subaşı, B., Budak, B., Çelik, M., Gürel, Ş. C. ve Yıldız, M. (2013). Ergenlik ve genç yetişkinlik dönemindeki kadınlarda benlik saygısı, sosyal görünüş kaygısı, depresyon ve anksiyete ilişkisi. Journal of Mood Disorders, 3(3), 107-113.

Özkan, İ. (1994). Benlik saygısını etkileyen etkenler. Düşünen Adam, 7(3), 4-9.

Özyürek, A., Özkan, İ., Begde, Z. ve Yavuz, N. F. (2019). İlkokul öğrencilerinde mükemmeliyetçi öz-sunum ve problem çözme becerileri. Çocuk ve Gelişim Dergisi, 2(4), 1-11.

Rosenberg, M. (1965). Rosenberg self-esteem scale (RSE). Acceptance and commitment therapy. Measures package, 61(52), 18.

Sarıçam, H. (2011). Üniversite öğrencilerinin reddedilme duyarlılıkları ile benlik saygıları ve yalnılık düzeyleri arasındaki ilişkinin incelenmesi. (Yayınlanmamış Yüksek Lisans Tezi). Atatürk Üniversitesi, Eğitim Bilimleri Enstitüsü, Erzurum.

Stoeber, J. and Roche, D. L. (2014). Affect intensity contributes to perfectionistic self-presentation in adolescents beyond perfectionism. Journal of Rational-Emotive \& Cognitive-Behavior Therapy, 32(2), 164-180.

Uçar, S. (2012). Üniversite öğrencilerinde mükemmeliyetçiliğin yordanması. (Yayınlanmamış Yüksek Lisans Tezi). Ege Üniversitesi, İzmir.

Uzunel, A. (2016). Lise öğrencilerinin anne-baba tutumları ile mükemmeliyetçi özsunum düzeyleri arasındaki ilişkinin incelenmesi (Kocaeli İli örneği).(Yüksek Lisans Tezi). Marmara Üniversitesi, Eğitim Bilimleri Enstitüsü, İstanbul. 
Vartanian, L. R. (2000). Revisiting the imaginary audience and personal fable constructs of adolescent egocentrism: A conceptual review. Adolescence, 35(140), 639.

Zeifman, R. J., Atkey, S. K., Young, R. E., Flett, G. L., Hewitt, P. L. and Goldberg, J. O. (2015). When ideals get in the way of self-care: Perfectionism and self-stigma for seeking psychological help among high school students. Canadian Journal of School Psychology, 30(4), 273287.

\section{Kaynakça Bilgisi / Citation Information}

Koçyiğit, A. ve Yalçın, A. F. (2021). Ergenlerin mükemmeliyetçi öz sunum düzeyleri ile sosyal görünüş kaygıları ve benlik saygıları arasındaki ilişki. OPUS- Uluslararası Toplum Araştırmaları Dergisi, 18(Eğitim Bilimleri Özel Sayıs1), 4875-4902. DOI: 10.26466/opus.924759. 